deed, inconsistency, leads him to some questionable juggling acts. A clear instance is when he lambasts the communists' "organic link" between the Comintern and the RILU only to go on to defend the trabazón (bond) between the CNT and the FAI. Equally, the syndicalists' apoliticism is initially praised and given as evidence of their primeval libertarian spirit when directed against socialists and communists, but is then attacked when it works against anarchist organisations. These are not the only examples in which important areas are overlooked, downplayed, or exaggerated, to suit Garner's agenda.

Goals and Means contains some persuasive and innovative elements and a broadly cogent argument, but, all in all, the biases of the author make it an unsatisfactory reading and an unwelcome relapse into the traditional anarcho-syndicalist historiography on the CNT.

Arturo Zoffmann Rodriguez

European History Institute

\title{
Petrus Liu, Queer Marxism in Two Chinas (Durham, NC: Duke University Press, 2015). 256pp. \$23.95 Paperback.
}

In Queer Marxism in Two Chinas Petrus Liu offers a model of queer theory that both challenges homonormative tendencies of mainstream neoliberal gay politics, and pulls on the possibilities of Marxist thought to provide a materialist, structural social analysis. I doubt readers of this journal will need much convincing that assimilationist, inclusion-based political projects are deeply flawed responses to injustice and exclusion, and this premise is of course the bedrock of anything that could rightfully be called "queer theory." At least I have always held to the ideological premise that queer theory and queerness are by definition rooted in analysis and critique of normativity in any area of social/psychic life, including, but not only, sexuality (yet, the sexual is never really absent from the picture it turns out). Challenging neoliberalism - the socio-economic structure that is widely supposed, as Liu points out, to be globally supplanting socialist and traditional liberal social models - is in fact the central agenda of much social theory scholarship; queer theory contributes to these critiques by providing a critical lens on the deeply structured functions of the sexual/gendered within ideologies and practices. However, as Liu presents the state of the field, the radical potential of queer theory is finding itself betrayed by the "homonormative movement" in which "queer" politics become subsumed into the neoliberal order through its assimilationist, normative, and consumerist grounding. "Queer liberalism," a term used to reference homonormative and assimilationist gay politics, is of course a paradox of meaning, but the term identifies the assimilationist bent of neoliberal global gay politics. Liu argues that this global gay politics, rooted in consumeristic, individualistic capitalist society, requires the corrective intervention that Marxist historical materialism can provide. 
Liu maps out the general contours of the multiple and often contradictory meanings of "queerness": as an analytic it challenges normativity; as a politics it is currently assumed to be assimilationist; as a sexuality it is a reimagining of "human community, intimacy, and connectedness" (97). While I am always uncomfortable with the slippage in using the term queer to refer both to an anti-normative analytic as well as to LGBTQ politics and identities more generally, I acknowledge that queer as a floating signifier has more lift than most. If we do not fret too much over the slippery usage of the term "queer," Liu presents a compelling account of "queer" Chinese Marxist infused productions. The significance of Liu's intervention is not so much the bemoaning of queer assimilationist politics, but rather the focus on China(s) to identify the intellectual and creative challenges to the neoliberal order, that he labels "Chinese Queer Marxism." The move to situate Chinese cultural productions as central to understanding the possibility of queer theory to address the transnational neoliberal order is an important corrective to the following "common sense" assumptions: Marxism and socialist thinking are discredited and dead within China(s) and beyond as vital intellectual frameworks for addressing contemporary sexual/gendered politics; queer theory and Marxism are inherently incompatible; queer theory and queer politics are exports from the West that replace and nullify pre-existing sexual systems and discourses transnationally.

The significance of Queer Marxism in Two Chinas is the demonstration that Chinese cultural productions, rooted in a Marxist sensibility if not methodology strictly speaking, challenge the widely held "common sense" assumption that queerness in China is a product of neoliberalism (3). Liu challenges the presumption within the field of queer studies that thinking about queerness and gayness in China by Chinese intellectuals and artists is necessarily subsumed within either Western queer theory discourses or neoliberal frameworks. Liu rejects the dominant revisionist historical narrative which asserts that neoliberalism frees the individual and their sexuality from the constraints of the socialist state, thereby producing the possibility of the queer. Liu also argues that the splitting of China into the socialist People's Republic of China (PRC) and the Western-aligned capitalist Republic of China (ROC) of Taiwan (the "two Chinas" of the title) was central to the development of Queer Marxism. This historical splitting in 1949 is central to understanding the development of Chinese Queer Marxism, with the ROC, perhaps surprisingly, acting as a central site for the development of Marxist-infused critiques of the social sexual order of neoliberalism and global capitalism.

Liu argues that Chinese Queer Marxism does not "reify alterity" by adding Chinese queers to the panoply of global case studies of local queerness (31); Liu is not arguing to add Chinese data or even Chinese thinking to the queer theory canon (but his work is in a sense an effort to challenge the canon). Rather, Liu's central argument is that Chinese Queer Marxism provides an analysis of "geopolitical ... relations of power" (31) and the structural analysis that is the hallmark of Marxist thought to identify queer radical thought. Chinese Queer Marxism is the antidote 
to the dominance of neoliberal frameworks of sexuality, gender, and power. I might quibble that structural analysis, based on either an explicit or implicit Marxist framework, is the bedrock of queer theory; as university lecturers we are always chanting the mantra of system and structure, not individual psychology, in understanding the roots of oppression. Left-leaning social theorists have always clung to their Marxist critiques of neoliberalism even as Marxism as a viable political/economic system has faded from conversation, as Liu rightly notes. The real delight in this text is the way Liu "traces the dynamic traditions of queer art, film, literature, social movements, and popular culture in the Chinas that produce a Marxist philosophy of human sociality" (31). Liu moves queer theory out of the academy to show how a coherent philosophy based on Marxist analysis has developed in the Chinas within the broader arena of artists and activists.

Liu beautifully fleshes out these broad theoretical claims when he introduces the reader to the actual examples of Chinese Queer Theory throughout the text. For example, one of the most remarkable queer Chinese artists Liu discusses, Cui Zi'en, in his "shocking and perverse" films, relies on spontaneity "as an anticapitalist mode of creativity" (49-50). Rather than focusing on the normative gay, neoliberal, "out and proud" subject, Cui includes "transvestites, voyeurs, boy toys, creepy uncles, gay-for-pay evangelists, bi-curious straight men, money boys, incestuous relatives, MTFs ... insatiable sluts, dinosaurs, reptiles, and extra-terrestrials ... subjects who are certainly 'queer' and living at some critical distance from cultural norms and power" (49). Neoliberal identity formation, along with the obligatory “coming out story," are impossible within Cui Zi'en's work, as Liu argues. Through these stories, Liu argues that Cui's work is "a reimagination of the possibilities of human sexuality, creativity, and fulfillment under conditions of reified labor" (4950). I will leave the reader to revel in Liu's nuanced discussion of the unruly, uncontained Queer Marxism of Cui and the many other artists covered. Throughout the text, Liu convincingly argues that the Chinas must not be reduced through an Orientalist lens to a field-site for the emergence of the global queer, but rather as the source of an analytic that provides the creative and intellectual space to lay bare the workings of neoliberal power and imagining that things could be otherwise.

Megan Sinnott Georgia State University

\section{Tim McCaskell, Queer Progress: From Homophobia to Homonationalism (Toronto: Between the Lines, 2016). 520pp. Paperback \$39.95.}

In Queer Progress: From Homophobia to Homonationalism Tim McCaskell quite comprehensively covers 40 years of activism within the LGBTQ movement, from 1974 2014. His capturing of these times is part subjective — as a gay activist he was part of the The Body Politic collective, contributed to the work of the Right to Privacy 